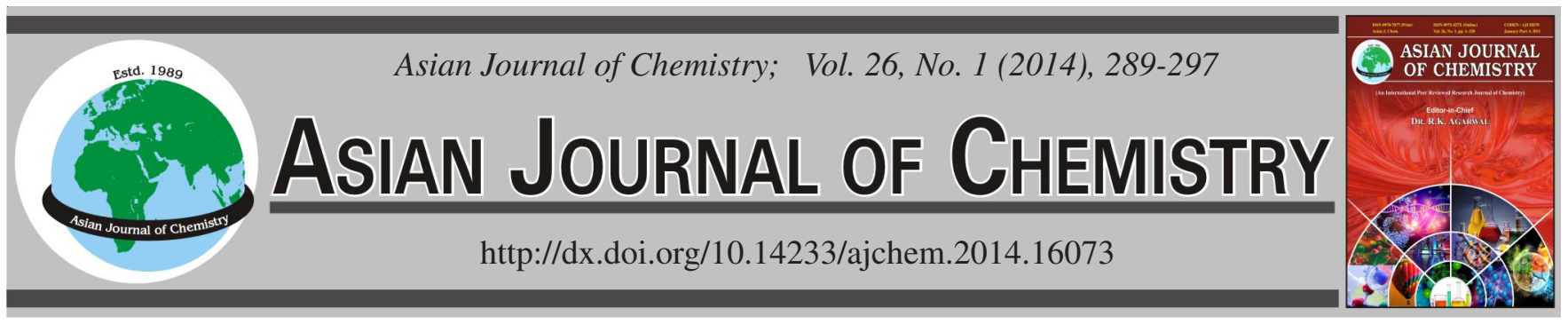

\title{
Low-Cost Schizandra chinesis Fruit Peel for Co(II) Removal from Aqueous Environment: Adsorption Properties and Mechanism
}

\author{
JANARdHAn Reddy Koduru ${ }^{1, *}$, Yoon-Young Chang ${ }^{2}$ and IM-SoOn Kim ${ }^{1}$
}

${ }^{1}$ Graduate School of Environmental Studies, Kwangwoon University, Seoul 139-701, Republic of Korea ${ }^{2}$ Department of Environmental Engineering, Kwangwoon University, Seoul 139-701, Republic of Korea

*Corresponding author: Fax: +82 2 9185774; Tel: +82 2 9405496; +82 10 86817816; E-mail: reddyjchem@gmail.com

\begin{abstract}
Biosorption is an ecofriendly wastewater treatment technique with high efficiency and low operating cost involving simple procedure for the removal and recovery of heavy metal ions from aqueous media. In present investigation, Schizandra chinesis fruit peel powder was utilized as biosorbent for the removal of $\mathrm{Co}$ (II) from aqueous media. The biosorbent was characterized by using Fourier transform infrared spectroscopy, scanning electron microscopy and energy dispersive X-ray techniques analysis. From FT-IR analysis it was found that hydroxyl, methoxy and carbonyl groups are involved in the removal of Co(II) from aqueous environment. The effect of various parameters for Co(II) removal by using Schizandra chinesis fruit peel powder are evaluated in batch biosorption method. Biosorption kinetics data was evaluated with kinetic models and the kinetic data was well fitted with pseudo-second-order kinetic model. The equilibrium data was in tune with the Langmuir isotherm model by revealing the maximum sorption capacity of $9.47 \mathrm{mg} \mathrm{g}^{-1}$ at $\mathrm{pH} 6.5$, contact time 40 min. This study demonstrated that the Schizandra chinesis fruit peel powder biosorbent was a promising, efficient, economic and biodegradable sorbent.
\end{abstract}

Keywords: Wastewater, Biosorption, Heavy metal, Cobalt, Schizandra chinesis fruit peel, Kinetic, Equilibrium, Adsorption mechanism.

\section{INTRODUCTION}

Heavy metals are significant environmental pollutants owing to their indefinite persistence in the environment and many of them are toxic even at very low concentrations. Many industrial activities (e.g. metal plating, fertilizer industry etc.) introduce heavy metals to environment via their waste effluents $^{1,2}$. Cobalt is a typical heavy metal because it has variety of industrial applications such as production of satellite alloys, paints, mining, metallurgical, electro plating, pigments and electronic. It was also present in the waste water from nuclear power plants and industrial effluents. Cobalt may causes serious health problems such as asthma leading to the damage of heart, its failure, damage to the functioning of thyroid gland and liver in humans $\mathrm{s}^{3-5}$ and also causes genetic changes in living cells $\mathrm{s}^{5-7}$. Cobalt ionization radiation exposure is associated with increasing risk of developing cancer ${ }^{5}$. Thus various regulatory bodies have set permissible limits for cobalt in drinking water. The EPA permissible limits of cobalt in the irrigation water and livestock wastewater are 0.05 and $1.0 \mathrm{mg} / \mathrm{L}$ respectively ${ }^{8-10}$ (Environmental Bureau of Investigation, Canadian Water Quality Guidelines).

Thus various techniques have been developed and employed for the treatment of cobalt from aqueous solutions.
The most conventional methods used for Co(II) removal from aqueous solutions include chemical precipitation, ion exchange/ chelation, electrolytic recovery, liquid-liquid extraction and membrane separation ${ }^{9-11}$. However, application of these methods are limited due to their technical and economical constraints, such as disadvantages like incomplete metal removal, high energy requirements, generation of toxic sludge or other waste products that require careful disposal. Hence it is imperative to explore a cost-effective treatment method that is capable of removing $\mathrm{Co}$ (II) from aqueous effluents ${ }^{10,12-14}$. This accelerated the search for highly efficient yet economically attractive treatment methods involving their removal from waste waters following the technique of biosorption ${ }^{8,15,16}$. In this perspective a number of researchers have been used biosorption technique for the removal of $\mathrm{Co}$ (II) from aqueous solution ${ }^{10,12,17-24}$. Biosorption has potential advantages over other traditional wastewater treatment technologies including low cost, high efficiency, minimization of chemical and low biological sludge, no additional nutrient requirement, regeneration of biosorbent and possibility of metal recovery and environmental friendly, particularly when natural biomass is used $^{25-31}$. One of important natural biomass is peel of various fruits, which can serve as a potential adsorbent for the removal 
of various types of environmental pollutants, especially metal ions ${ }^{32-35}$. Schizandra chinesis is a vine with flowers and fruits that grows in Russia, China, Korea and Japan, is an excellent source of biomass for the chelating of heavy metals and its applications to eliminate these contaminants from underground water as well as contribute or reduce the organic pollution due to this kind of wasters in places with string fruit in Korea. The biomass of Schizandra chinesis consists of nine lignans bioactive compounds ${ }^{36}$. The fruits of Schizandra chinesis have been used to treat chronic cough, spontaneous sweating, palpitation and spermatorrhea as tonic and sedative in various prescriptions in traditional Chinese medicines ${ }^{37,38}$.

This work is to demonstrate that the use of modified waste material from Schizandra chinesis fruit peel (SCFP) as a biosorbent for the removal of $\mathrm{Co}$ (II) from aqueous solutions. Various experimental parameters such as equilibrium, $\mathrm{pH}$ effect, biosorbent dosage, contact time and initial metal ion concentration were performed in order to optimize the process variables for the removal of $\mathrm{Co}(\mathrm{II})$. Langmuir, Freundlich and Temkin adsorption isotherm models were used to determine the mechanism of the biosorption process. The developed method was successfully applied for the removal of $\mathrm{Co}$ (II) from aqueous solutions. The report is first of its kind about using biomass, SCFP as a biosorbent for the removal of metal ions.

\section{EXPERIMENTAL}

Preparation of the biosorbent: Schizandra chinesis fruits peel was collected from Oriental Medical College, Gyeongju, South Korea. The peel was removed from the fruits and was cut into small pieces. These pieces were air dried and grounded in a mill to get fine powder. The powder was washed twice with deionizer water and dried at $60^{\circ} \mathrm{C}$ for $24 \mathrm{~h}$, then boiled in double distilled water by changing the water repeatedly until water becomes colourless, which indicates that the removal of water soluble colour compounds. The washed and boiled fine powder was oven dried at $70{ }^{\circ} \mathrm{C}$ for $24 \mathrm{~h}$ and stored in desiccators to prevent from moisture adsorption. This was named as SCFP biosorbent.

Chemicals and equipments: Standard metal solution (analytical grade) containing $1000 \mathrm{mg} \mathrm{L}^{-1}$ of $\mathrm{Co}(\mathrm{II})$ was prepared from cobalt acetate $\left[\mathrm{Co}\left(\mathrm{CH}_{3} \mathrm{COO}\right)_{2} \cdot 4 \mathrm{H}_{2} \mathrm{O}\right]$ purchased from Sigma-Aldrich (Ireland). Working solutions were prepared by diluting the standard solution with distilled water. $\mathrm{pH}$ of the samples was measured by $\mathrm{pH}$ meter (pH 340i, WTW, Germany) after calibration using standard buffer solutions for three times. The metal concentrations in solution were determined using Varian Spectra AA220 model atomic absorption spectrometer (AAS). The morphology and elemental composition of the biosorbent was analyzed using scanning electron microscope with an energy dispersive X-ray spectroscopy (S-4300 \& EDX-350, Hitachi, Japan). Surface area and pore sizes of the biosorbent were measured by Brunauer-EmmettTeller method (BET) (Autosorb-1, Quanta chrome instrument, USA) based on $\mathrm{N}_{2}$ gas adsorption on the surface of biosorbent at $60{ }^{\circ} \mathrm{C}$. The functional groups present in the biosorbents were analyzed by using spectrum GX \& Auto image (Perkin-Elmer, USA) FTIR spectra from 4000 to $400 \mathrm{~cm}^{-1}$ spectral range using Ge coated $\mathrm{KBr}$ beam splitter.
Batch biosorption studies: Batch biosorption studies were carried out by shaking $0.1 \mathrm{~g}$ of biomass (SCFP) with $50 \mathrm{~mL}$ of the aqueous solutions of $\mathrm{Co}$ (II) ions at $\mathrm{pH} 6.5$ in different conical flask using a temperature controlled shaker $\left(25 \pm 2{ }^{\circ} \mathrm{C}\right)$. The solution-biosorbents mixtures were stirred at $200 \mathrm{rpm}$ and at the end of pre-determined time interval the reaction mixtures were filtered out and analyzed for its metal ion concentrations by using AAS. The biosorption experiments were also conducted to determine the equilibrium time (10$60 \mathrm{~min})$, initial concentrations $\left(6-20 \mathrm{mg} \mathrm{L}^{-1}\right)$ and dosage of the adsorbent $\left(1-4 \mathrm{~g} \mathrm{~L}^{-1}\right)$ for maximum biosorption. All the investigations were carried out in duplicate to avoid any discrepancy in experimental results and metal solution controls were kept throughout the experiment to maintain quality control. The percentage of metal biosorption was measured using the equation:

$$
\text { Biosorption }(\%)=\left(\frac{\mathrm{C}_{\mathrm{i}}-\mathrm{C}_{\mathrm{f}}}{\mathrm{C}_{\mathrm{i}}}\right) \times 100
$$

where $C_{i}$ and $C_{e}$ or $C_{f}$ are the initial and equilibrium or final concentration of metal ion $\left(\mathrm{mg} \mathrm{L}^{-1}\right)$, respectively in the solution. Biosorption capacity was calculated by using the mass balance equation for the biosorbent:

$$
\mathrm{q}_{\mathrm{e}}=\frac{\left(\mathrm{C}_{\mathrm{o}}-\mathrm{C}_{\mathrm{e}}\right) \mathrm{V}}{\mathrm{m}}
$$

where $\mathrm{q}_{\mathrm{e}}$ is the biosorption capacity $\left(\mathrm{mg} \mathrm{g}^{-1}\right), \mathrm{V}$ is the volume of metal ion solution (L) and $\mathrm{m}$ is the weight of the biosorbent (g).

Kinetics biosorption studies were also carried out in order to determine the contact time required to reach the equilibrium at constant $\mathrm{pH}$, biosorbent dosage and metal initial concentration with varying contact time. The amount of adsorption capacity at time $t$, was measured using the following equation:

$$
\mathrm{q}_{\mathrm{t}}=\frac{\left(\mathrm{C}_{\mathrm{o}}-\mathrm{C}_{\mathrm{t}}\right) \mathrm{V}}{\mathrm{m}}
$$

where $\mathrm{C}_{\mathrm{t}}\left(\mathrm{mg} \mathrm{L}^{-1}\right)$ is the concentration of metal ion at particular time, $\mathrm{t}$ in the present experiment.

\section{RESULTS AND DISCUSSION}

Physical characterization of the Schizandra chinesis fruits peel (SCFP) biosorbent: Characteristics of SCFP biomass such as bulk density, moisture content, ash content, surface area, surface composition and other physical parameters were measured (Table-1). The bulk density of the biomass was found to be $0.45-0.55 \mathrm{~g} \mathrm{~mL}^{-1}$ with $1.2 \%$ moisture and $12.54 \%$ of ash content, respectively. The BET surface area of biomass was found to be $445 \mathrm{~m}^{2} \mathrm{~g}^{-1}$ by using $\mathrm{N}_{2}$ gas adsorption method. The pore volume and pore mean diameter were also measured and reported in Table-1. From the pore mean diameter $(43.5 \AA)$ of biomass, it was confirmed as mesopores sorbent [20 $\mathrm{A}<\mathrm{d}<500 \AA$; International Union of Pure and Applied Chemistry (IUPAC)].

Optimization of batch biosorption: Biosorption of heavy metal ions onto the surface of a SCFP is affected by several factors, such as biomass concentration, initial $\mathrm{pH}$, initial metal ion concentration, time and temperature. In order to optimize 


\begin{tabular}{lc}
\hline \multicolumn{2}{c}{ TABLE-1 } \\
\multicolumn{2}{c}{ PHYSICAL CHARACTERISTICS OF } \\
SCFP POWDER BIOSORBENT \\
\hline \multicolumn{1}{c}{ Physical characteristics } & Values \\
\hline Bulk density & $0.45-0.55 \mathrm{~g} \mathrm{~mL}^{-1}$ \\
Moisture content & $1.20 \%$ \\
Ash content & $12.54 \%$ \\
Surface area & $445 \mathrm{~m}^{2} \mathrm{~g}^{-1}$ \\
Pore volume & $0.718 \mathrm{~cm}^{3} \mathrm{~g}^{-1}$ \\
Pore mean diameter & $43.45 \AA$ \\
\hline
\end{tabular}

the effect of these parameters batch biosorption experiments were carried out as follows:

Effect of biomass dosage: The number of sites available for biosorption depends upon the amount of the biosorbent. Effect of biosorbent dosage ( 1 to $\left.4 \mathrm{~g} \mathrm{~L}^{-1}\right)$ on metal $\left(20 \mathrm{mg} \mathrm{L}^{-1}\right)$ removal efficiency was studied at $\mathrm{pH} 6.5$ at $25 \pm 2{ }^{\circ} \mathrm{C}$ controlled water bath for $40 \mathrm{~min}$. The percentage of metal ions uptake was found to be on the rise with the increasing concentration of the biosorbent but the amount of metal adsorbed per unit mass decreased considerably. The increase in the biosorption percentage or decrease in unit biosorption with increase in the dose of biosorbent is due to the increase in active sites on the adsorbent and thus making easier penetration of the metal ions to the biosorption sites. It may be due to the formation of biosorbent agglomerates or interactions between sorbent atoms reducing available surface area and blocking some of the biosorption sites ${ }^{39,40}$. Maximum removal of $\mathrm{Co}$ (II) ions was observed with an biosorbent dose of $2 \mathrm{~g} \mathrm{~L}^{-1}$ and there after a slow increase in the percentage removal was seen reaching a constant value with respect to the biosorbent dosage.

Effect of pH: The $\mathrm{pH}$ of the solution is well known characteristic that affects the surface charge of adsorbents by the protonation of functional groups in the biomass, as well as the degree of ionization and chemistry of the metal ions. The optimum $\mathrm{pH}$ for $\mathrm{Co}$ (II) biosorption was investigated by adding $2 \mathrm{~g} \mathrm{~L}^{-1}$ SCFP biomass to aqueous metal solution and was adjusted to various $\mathrm{pH}$ values (2 to 12 ) using $0.1 \mathrm{~mol} \mathrm{~L}^{-1}$ $\mathrm{NaOH}$ or $0.1 \mathrm{~mol} \mathrm{~L}^{-1} \mathrm{HCl}$. Flasks were shaken for $40 \mathrm{~min}$ at $200 \mathrm{rpm}$ at $25 \pm 2{ }^{\circ} \mathrm{C}$. As shown in Fig. 1, the metal uptake was increased with increase of $\mathrm{pH}$ in the range of 2 to 6 and after that it was almost constant and achieved maximum sorption capacity values above $\mathrm{pH}$ 6. At lower $\mathrm{pH}$ lower biosorption capacity was observed this is due to the fact that the concentrations of protons and hydronium $\left(\mathrm{H}_{3} \mathrm{O}^{+}\right)$ions was higher and this compete for the binding of active sites on the surface of the biosorbent with metal ions. Further with increasing $\mathrm{pH}$ there is a decrease in competition between the protons surrounded by the adsorbent and metal ions. When the $\mathrm{pH}$ of the solution was increased from $\mathrm{pH} 2$ to 6 the number of negatively charged sites increased and resulting in increased biosorption. Further the biosorption capacity was almost constant above the $>\mathrm{pH} 6.5$ there is no significant change in adsorption was observed.

Effect of $\mathrm{pH}$ on biosorption can also explained based on the $\mathrm{Co}$ (II) species distribution as the function of solution $\mathrm{pH}^{9,41}$. According to Huang et al. ${ }^{41}$ the chemical precipitation of $\mathrm{Co}$ (II) started at above the $\mathrm{pH} 8$. This means $\mathrm{Co}(\mathrm{II})$ remains as the prevailing species up to a $\mathrm{pH}$ value of 8 . Above $\mathrm{pH} 8$, the

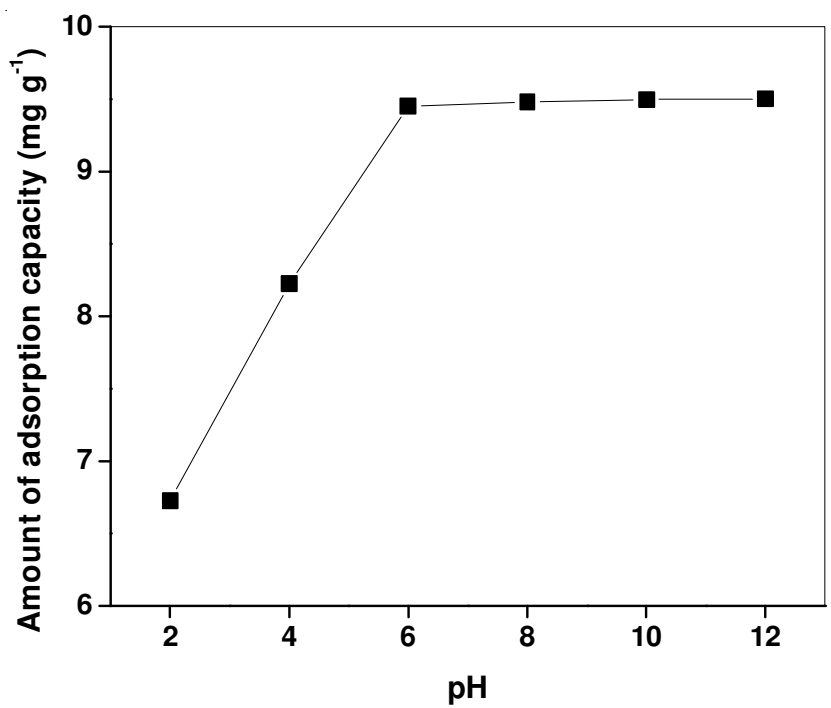

Fig. 1. Effect of $\mathrm{pH}$ on biosorption of $\mathrm{Co}(\mathrm{II})$ using $\mathrm{SCFP}\left(2 \mathrm{~g} \mathrm{~L}^{-1}\right)$ as biosorbent at $20 \mathrm{mg} \mathrm{L}^{-1} \mathrm{Co}$ (II) initial concentration, $25 \pm 2{ }^{\circ} \mathrm{C}$ temperature and $200 \mathrm{rpm}$ shaking speed for $40 \mathrm{~min}$ equilibrium time

$\mathrm{Co}(\mathrm{II})$ species are available as $[\mathrm{Co}(\mathrm{OH})]^{+}$and $\mathrm{Co}(\mathrm{OH})_{2}$. Above $\mathrm{pH} 8, \mathrm{Co}$ (II) was adsorbed onto negative surface of biosorbent along with chemical precipitation of $\mathrm{Co}$ (II) as hydroxide at above $\mathrm{pH}$ 8. Hence, $\mathrm{pH} 6.5$ was choosing for further studies.

Effect of contact time and Initial concentration: Effect of contact time is one of the most important factors that affecting the biosorption efficiency. In order to study the effect of contact time on metal ion removal batch sorption experiments were carried with metal ions (initial concentration 6 to $\left.20 \mathrm{mg} \mathrm{L}^{-1}\right)$ and SCFP biomass $\left(2 \mathrm{~g} \mathrm{~L}^{-1}\right)$ as a function of contact time (10 to $60 \mathrm{~min}$ ) in a temperature controlled shaking water bath at $25 \pm 2{ }^{\circ} \mathrm{C}$. It has been observed that the within the first 10 min rapid biosorption of metal ion was observed (Fig. 2). After this period the amounts of biosorption was slowed down until it reaches the equilibrium. The possible reason for the phenomenon is a large number of vacant surface sites which are available for biosorption during the initial stage and after a lapse of time the remaining vacant surface sites find it difficult to get occupied due to repulsive forces between the solute molecules on the solid and aqueous phases. Similar results were observed by some researcher for the different adsorbatesorbent system ${ }^{42,43}$. Based on the results $40 \mathrm{~min}$ was fixed for further batch biosorption experiments to assume that the equilibrium is achieved. As shown in Fig. 2, when increase initial concentration of $\mathrm{Co}$ (II) from 6 to $20 \mathrm{mg} \mathrm{L}^{-1}$ the absolute sorption per unit weight of biosorbent increased. However, the percentage of $\mathrm{Co}$ (II) biosorption decreases with increasing initial concentration. It is due to the available active sorption sites became fewer at higher initial concentration. It concluded that the $\mathrm{Co}$ (II) biosorption is concentration dependent. Similar results were reported by some of researchers for different sorption systems ${ }^{9}$.

Kinetic studies of biosorption: The biosorption kinetics studies have carried out to determine the rate of biosorption which is important for designing treatment systems. The kinetics of biosorption of Co(II) onto SCFP biomass were investigated for three initial concentrations varying between 6 to $20 \mathrm{mg} \mathrm{L}^{-1}$. The experimental data were analyzed by the 


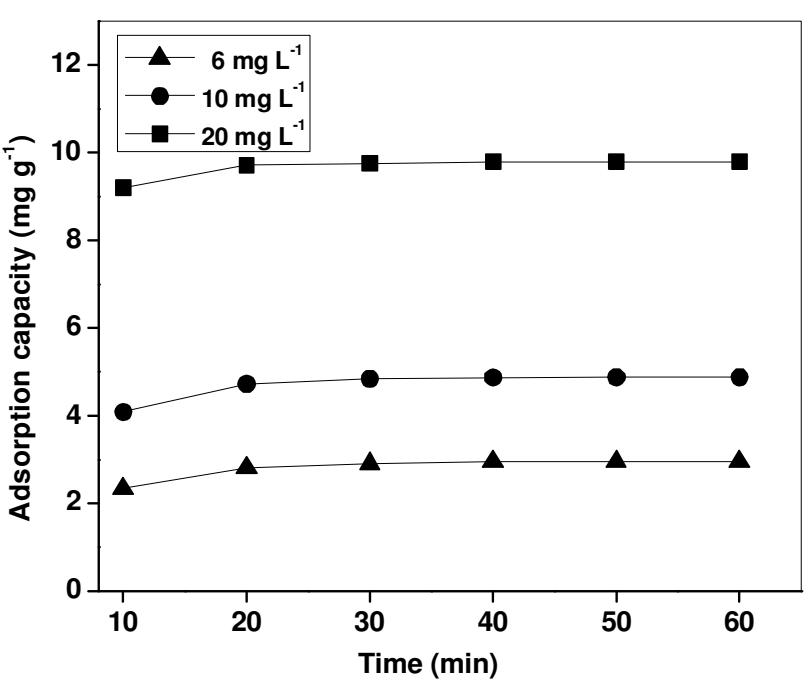

Fig. 2. Effect of contact time and initial metal ion concentration on biosorption of $\mathrm{Co}$ (II) using SCFP $\left(2 \mathrm{~g} \mathrm{~L}^{-1}\right)$ as biosorbent at $25 \pm$ $2{ }^{\circ} \mathrm{C}$ and $200 \mathrm{rpm}$ shaking speed and varying the $\mathrm{Co}$ (II) initial concentration from 6 to $20 \mathrm{mg} \mathrm{L}^{-1}$

pseudo first-order and pseudo-second-order kinetic models. The conformity between experimental data and the model predicted values was expressed by correlation coefficient $\left(\mathrm{R}^{2}\right)$.

The linear pseudo-first order model was proposed by Lagergren $^{44}$, describes the rate of sorption is proportional to the number of sites unoccupied by the solutes is expressed as follows:

$$
\log \left(\mathrm{q}_{\mathrm{e}}-\mathrm{q}_{\mathrm{t}}\right)=\log \left(\mathrm{q}_{\mathrm{e}}\right)-\left(\mathrm{K}_{\mathrm{l}} / 2.303\right) \mathrm{t}
$$

where $\mathrm{q}_{\mathrm{t}}$ and $\mathrm{q}_{\mathrm{e}}$ are the metal ion concentrations $\left(\mathrm{mg} \mathrm{g}^{-1}\right)$ at any time $(\mathrm{t})$ and at the equilibrium $\left(\mathrm{mg} \mathrm{g}^{-1}\right)$, respectively and $\mathrm{K}_{1}$ is the first order rate constant $\left(\mathrm{min}^{-1}\right)$ which is obtained from slope of the $\log \left(\mathrm{q}_{\mathrm{e}}-\mathrm{q}_{\mathrm{t}}\right)$ versus $\mathrm{t}$ at different initial concentration of $\mathrm{Co}$ (II) (Fig. 3). The constant value $\mathrm{K}_{1}$ and correlation coefficient $\left(\mathrm{R}^{2}\right)$ summarized in Table-2. The correlation coefficient values for biosorption of $\mathrm{Co}$ (II) indicates that the pseudofirst order kinetics was not fitted well to biosorption kinetic data. The pseudo-first order model works effectively only in the region where biosorption process occurs rapidly.

\begin{tabular}{|c|c|c|c|}
\hline \multicolumn{4}{|c|}{$\begin{array}{c}\text { TABLE-2 } \\
\text { KINETICS PARAMETERS OF Co(II) } \\
\text { BIOSORPTION ON TO SCFP BIOSORBENT }\end{array}$} \\
\hline \multirow{2}{*}{$\begin{array}{c}\text { Kinetics } \\
\text { parameters }\end{array}$} & \multicolumn{3}{|c|}{ Initial metal ion concentration $\left(\mathrm{mg} \mathrm{L}^{-1}\right)$} \\
\hline & 6 & 10 & 20 \\
\hline $\mathrm{q}_{\text {e.exp. }}\left(\mathrm{mg} \mathrm{g}^{-1}\right)$ & 2.949 & 4.879 & 9.787 \\
\hline \multicolumn{4}{|c|}{ Pseudo-first-order kinetics } \\
\hline $\mathrm{q}_{\mathrm{e}, \text { call }}\left(\mathrm{mg} \mathrm{g}^{-1}\right)$ & 17.92 & 4.12 & 2.69 \\
\hline $\mathrm{K}_{1}\left(\min ^{-1}\right)$ & 0.078 & 0.135 & 0.168 \\
\hline $\mathrm{R}^{2}$ & 0.850 & 0.999 & 0.956 \\
\hline \multicolumn{4}{|c|}{ Pseudo-second-order Kinetics } \\
\hline $\mathrm{q}_{\mathrm{ecal}}\left(\mathrm{mg} \mathrm{g}^{-1}\right)$ & 3.098 & 5.053 & 9.898 \\
\hline $\mathrm{K}_{2}\left(\mathrm{~g} \mathrm{mg}^{-1} \min ^{-1}\right)$ & 0.131 & 0.113 & 0.188 \\
\hline $\mathrm{h}\left(\mathrm{mg} \mathrm{g}^{-1} \min ^{-1}\right)$ & 1.26 & 2.89 & 18.38 \\
\hline $\mathrm{R}^{2}$ & 0.999 & 0.999 & 0.999 \\
\hline
\end{tabular}

Ho et al..$^{45}$ noticed that the use of the Lagergren model for prediction of the biosorption kinetics is not suitable for the entire sorption period. Thus, Ho et al. ${ }^{45}$ developed pseudosecond order kinetic model expressed in the following form:
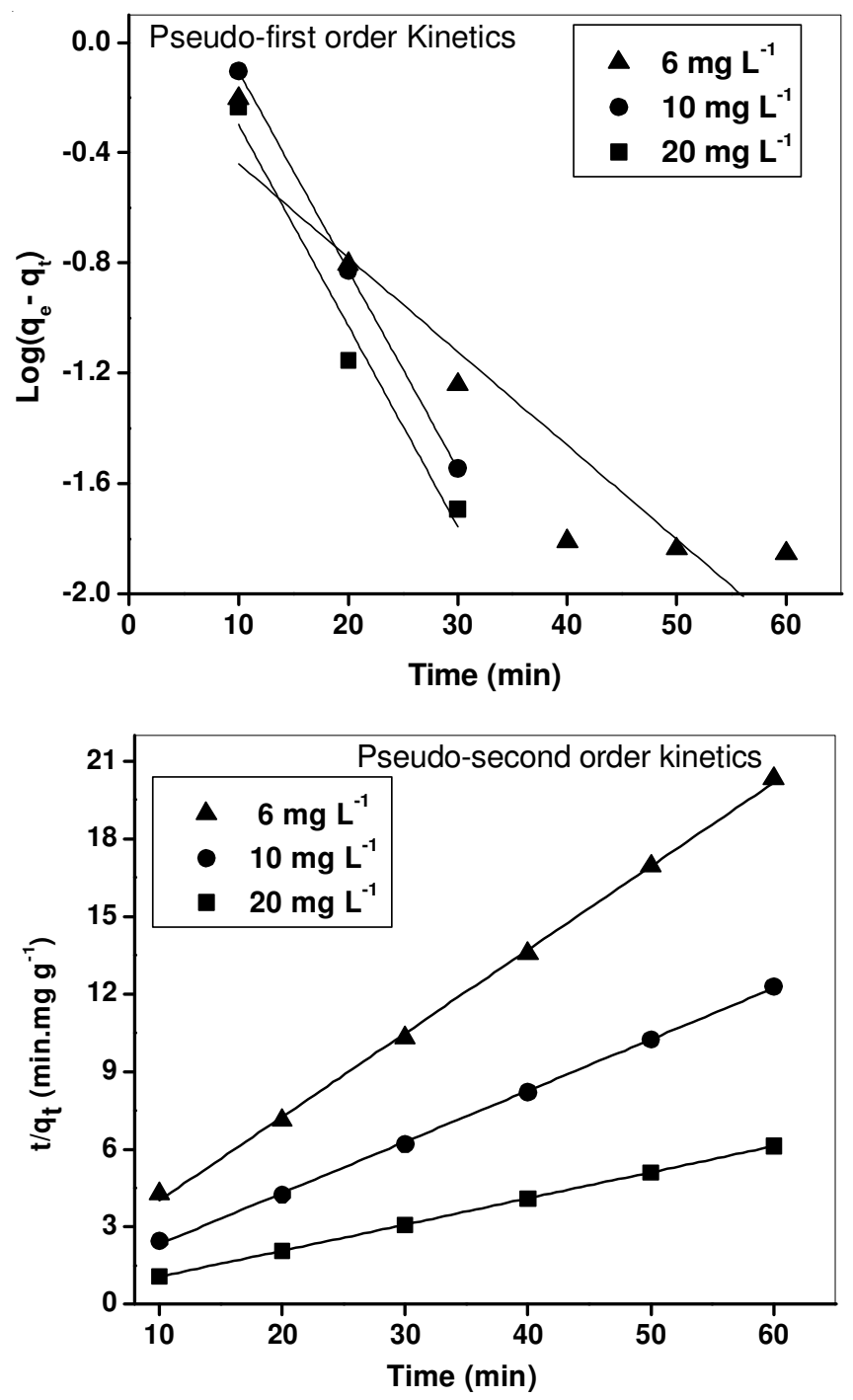

Fig. 3. Pseudo-first order and pseudo-second order kinetics for $\mathrm{Co}(\mathrm{II})$ biosorption on to SCFP biomass as a biosorbent

$$
\mathrm{t} / \mathrm{q}_{\mathrm{t}}=1 /\left(\mathrm{K}_{2} \mathrm{q}_{\mathrm{e}}^{2}\right)+\left(1 / \mathrm{q}_{\mathrm{e}}\right) \mathrm{t}
$$

where $\mathrm{q}_{\mathrm{t}}$ is the metal ion concentration $\left(\mathrm{mg} \mathrm{g}^{-1}\right)$ at time $(\mathrm{t})$ and is the metal ion concentration the equilibrium $\left(\mathrm{mg} \mathrm{g}^{-1}\right)$ and is the pseudo second order rate constant $\left(\mathrm{g} \mathrm{mg}^{-1} \mathrm{~min}^{-1}\right)$. A plot was drawn between $\mathrm{t} / \mathrm{q}_{\mathrm{t}}$ and $\mathrm{t}$ using eqn. 5 and fit liner curve (Fig. 3). From the slope and intercept of the curve $q_{e}, K_{2}$ and correlation coefficient $\left(\mathrm{R}^{2}\right)$ were calculated and the obtained results were summarized in Table-2. The correlation coefficient values obtained from pseudo-second-order model were ranged from 0.998 to 0.999 indicate the applicability of pseudosecond-order model for the biosorption data of $\mathrm{Co}$ (II) on to SCFP biomass. From the comparison of the two kinetic models, we can conclude that the biosorption of Co(II) onto the SCFP biomass follows the pseudo second-order kinetics.

Isotherm studies of biosorption: A biosorption isotherm is characterized by certain values, which express the surface properties and affinity of the biosorbent ${ }^{46,47}$. Sorption equilibrium data can be described by a number of isotherm models available in the literature. In this study, Langmuir, Freundlich and Temkin isotherm models were selected to analyze the experimental data at different adsorbent dosage at $25 \pm 2{ }^{\circ} \mathrm{C}$. 
The Langmuir isotherm mode ${ }^{48}$ which describes, that the sorption process takes place at a specific sorption surface with homogeneous adsorption energy. It is based on the assumption that the maximum adsorption corresponds to a saturated monolayer of solute molecules on the adsorbent surface, with no lateral interaction between the adsorbed molecules ${ }^{49}$. This model is expressed as follows:

$$
\mathrm{C}_{\mathrm{e}} / \mathrm{q}_{\mathrm{e}}=1 / \mathrm{b}\left(1 / \mathrm{K}_{\mathrm{L}}\right)+1 / \mathrm{b}\left(\mathrm{C}_{\mathrm{e}}\right)
$$

where $\mathrm{q}_{\mathrm{e}}$ is the metal uptake capacity and $\mathrm{C}_{\mathrm{e}}$ is the concentration of metal ions in the solution at equilibrium, $b$ is the maximum uptake capacity when the surface is completely covered with metal ions that represents the affinity between the biosorbent and the metal ion and $\mathrm{K}_{\mathrm{L}}$ is the Langmuir equilibrium constant or rate of adsorption. The plot drawn between $\mathrm{C}_{\mathrm{e}} / \mathrm{q}_{\mathrm{e}}$ versus $\mathrm{C}_{\mathrm{e}}$ and fitted linear curve was shown in Fig. 4. The slope of curve indicates $(1 / \mathrm{b})$ and where as an intercept indicates $1 / \mathrm{bK} \mathrm{L}_{\mathrm{L}}$. The correlation coefficients $\left(\mathrm{R}^{2}\right)$, values observed for $\mathrm{Co}(\mathrm{II})$ biosorption onto SCFP were 0.985 and 0.998 at 2 and $4 \mathrm{~g} \mathrm{~L}^{-1}$ adsorbent dosages respectively. This indicates that the biosorption of Co(II) onto SCFP biomass was compatible with the Langmuir isotherm. The isotherm constants of Langmuir, $\mathrm{K}_{\mathrm{L}}$ and $\mathrm{b}$ were calculated and are reported in Table-3. The essential characteristics of the Langmuir isotherm can be expressed in terms of a dimensionless constant separation factor $\mathrm{R}_{\mathrm{L}}$ and as expressed in the follows ${ }^{49,50}$ :

$$
\mathrm{R}_{\mathrm{L}}=1 /\left(1+\mathrm{K}_{\mathrm{L}} \mathrm{C}_{\mathrm{o}}\right)
$$

where $\mathrm{C}_{\mathrm{o}}$ is the highest initial concentration of adsorbate (mg $\left.\mathrm{L}^{-1}\right)$ and $\mathrm{K}_{\mathrm{L}}\left(\mathrm{L} \mathrm{mg}^{-1}\right)$ is the Langmuir constant. The $\mathrm{R}_{\mathrm{L}}$ values indicates the shape of the isotherm to be either favourable $(0$ $\left.<\mathrm{R}_{\mathrm{L}}<1\right)$, Linear $\left(\mathrm{R}_{\mathrm{L}}=1\right)$, unfavourable $\left(\mathrm{R}_{\mathrm{L}}>1\right)$, or irreversible $\left(R_{L}=0\right)$. The $R_{L}$ value in the present investigations were found to be 0.255 and $0.090\left(0<R_{L}<1\right)$ at $25^{\circ} \mathrm{C}$ with 2 and $4 \mathrm{~g} \mathrm{~L}^{-1}$ adsorbent dosage respectively, indicating that the sorp-

\begin{tabular}{|c|c|c|}
\hline \multicolumn{3}{|c|}{$\begin{array}{c}\text { TABLE-3 } \\
\text { ISOTHERM PARAMETERS OF Co(II) } \\
\text { BIOSORPTION ON TO SCFP BIOSORBENT }\end{array}$} \\
\hline \multirow{2}{*}{ Adsorption isotherm and its constants } & \multicolumn{2}{|c|}{ Adsorbent dosage $\left(\mathrm{g} \mathrm{L}^{-1}\right)$} \\
\hline & 2 & 4 \\
\hline \multicolumn{3}{|c|}{ Langmuir adsorptions isotherms constants } \\
\hline Maximum adsorption capacity, $\mathrm{b}\left(\mathrm{mg} \mathrm{g}^{-1}\right)$ & 9.47 & 18.23 \\
\hline $\mathrm{K}_{\mathrm{L}}\left(\mathrm{L} \mathrm{mg}^{-1}\right)$ & 0.146 & 0.504 \\
\hline $\mathrm{R}^{2}$ & 0.985 & 0.998 \\
\hline \multicolumn{3}{|c|}{ Freundlich adsorption isotherms constants } \\
\hline $\mathrm{K}_{\mathrm{F}}\left(\mathrm{mg} \mathrm{g}^{-1}\right)\left(\mathrm{L} \mathrm{mg}^{-1}\right)^{1 / n}$ & 13.52 & 6.80 \\
\hline $\mathrm{N}$ & 1.136 & 1.124 \\
\hline $\mathrm{R}^{2}$ & 0.998 & 0.998 \\
\hline \multicolumn{3}{|c|}{ Temkin adsorption isotherms constants } \\
\hline $\mathrm{K}_{\mathrm{T}}\left(\mathrm{L} \mathrm{mg}^{-1}\right)$ & 17.14 & 16.87 \\
\hline B & 7.82 & 3.94 \\
\hline $\mathrm{R}^{2}$ & 0.922 & 0.917 \\
\hline
\end{tabular}
tion of Co(II) on SCFP biomass is favourable.

The Freundlich isotherms is an empirical expression that takes into account the heterogeneity of the surface and multilayer adsorption to the binding sites located on the surface of the sorbent. The Freundlich ${ }^{51}$ model is expressed as follows:

$$
\ln \mathrm{q}_{\mathrm{e}}=\ln \mathrm{K}_{\mathrm{F}}+1 / \mathrm{n} \ln \mathrm{C}_{\mathrm{e}}
$$
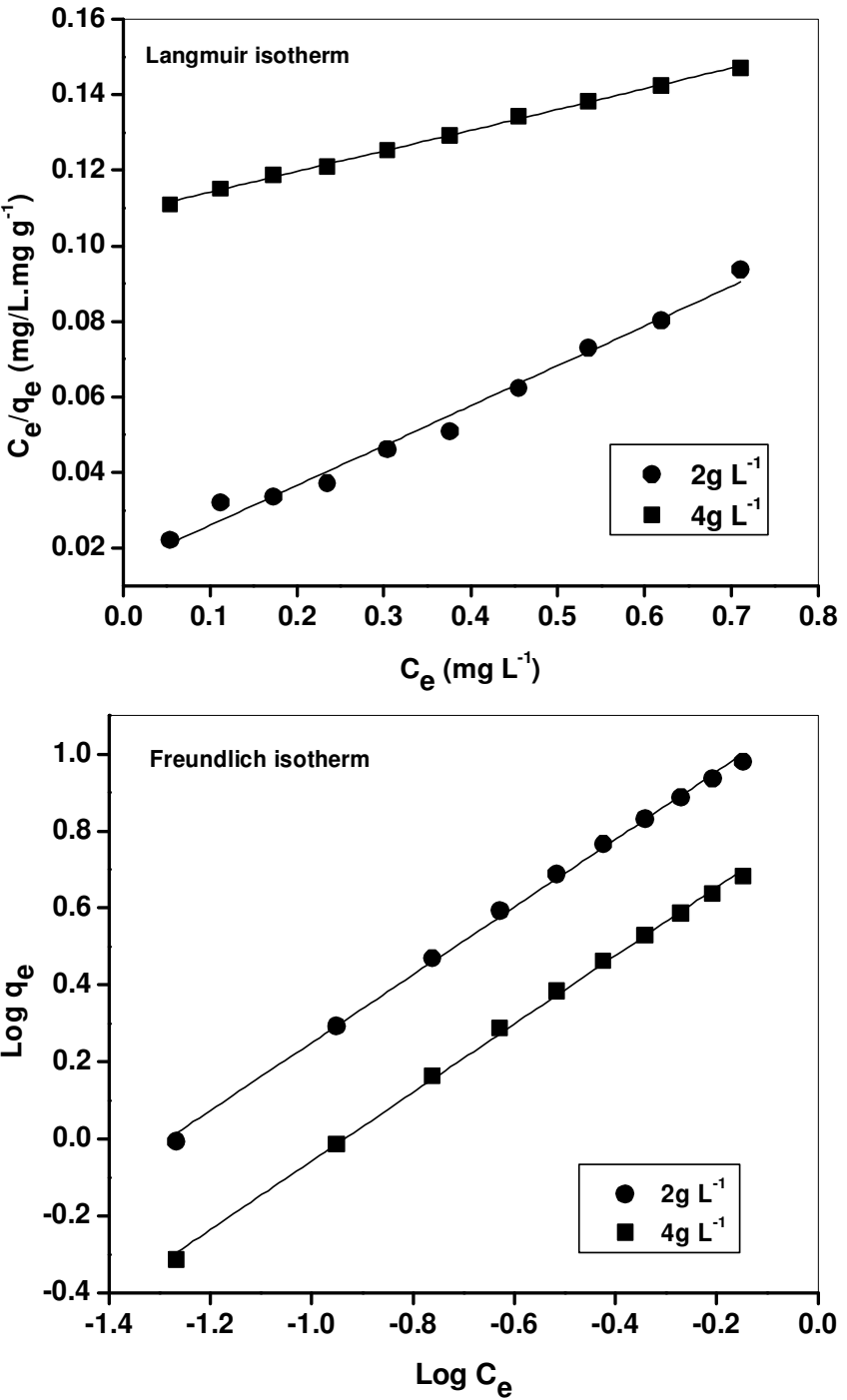

Fig. 4. Langmuir and Freundlich adsorption isotherms of Co(II) on to SCFP biomass as a biosorbent

Based on Freundlich eqn. 8, a plot drawn between $\ln \mathrm{C}_{\mathrm{e}}$ and $\ln \mathrm{q}_{\mathrm{e}}$ (Fig. 4) should be a straight line with a slope (1/n) is an empirical constant indicates the biosorption intensity and an intercept $\ln \mathrm{K}_{\mathrm{F}}$ where $\mathrm{K}_{\mathrm{F}}$ is the biosorption equilibrium constant. The correlation coefficients $\left(\mathrm{R}^{2}\right), 0.998$ at two different adsorbent dosages ( 2 and $4 \mathrm{~g} / \mathrm{L}$ ) and $\mathrm{n}>1$ indicates that the biosorption of $\mathrm{Co}$ (II) onto SCFP is well fitted to Freundlich isotherm. The Freundlich isotherm parameters were reported in Table-3.

Temkin and Pyzhev ${ }^{52}$ considered the effects of indirect adsorbate/adsorbate interactions on adsorption isotherms. The Temkin isotherm has been used in the following form:

$$
\mathrm{q}_{\mathrm{e}}=\mathrm{RT} / \mathrm{b} \ln \left(\mathrm{K}_{\mathrm{T}} \mathrm{C}_{\mathrm{e}}\right)
$$

This equation can be expressed in its linear form as:

$$
\mathrm{q}_{\mathrm{e}}=\mathrm{B} \ln \mathrm{K}_{\mathrm{T}}+\mathrm{b} \ln \mathrm{C}_{\mathrm{e}}
$$

where $\mathrm{B}=(\mathrm{RT} / \mathrm{b})$, which is obtained from the slope of plot $\mathrm{q}_{\mathrm{e}}$ versus $\ln \mathrm{C}_{\mathrm{e}}$. The intercept of curve indicates $\mathrm{B} \ln \mathrm{K}_{\mathrm{T}}$. The isotherm constants $\mathrm{K}_{\mathrm{T}}$ and $\mathrm{BK}_{\mathrm{T}}$ is the Temkin equilibrium binding constants $(\mathrm{L} / \mathrm{mg})$ corresponding to the maximum binding energy and constant B is related to heat of adsorption and the reset of term as usual have significance. The calculated 
isotherms constants were reported in Table-3. It was not in tune with the adsorption data of $\mathrm{Co}$ (II) which was predicted by the $\mathrm{R}^{2}$ values of this isotherms.

From Table-3, the Langmuir and Freundlich adsorption isotherm models yielded best results as indicated by the highest $\mathrm{R}^{2}$ values at different biosorbent dosage compared to Temkin adsorption isotherm models. Best fitting of the equilibrium data with both Langmuir and Freundlich isotherms suggest that biosorbent surface contains both homogeneous and heterogeneously distributed active sites.

Comparison of Co(II) biosorption on to SCFP with other biosorbents: Biosorption capacities of various biosorbents towards $\mathrm{Co}$ (II) removal reported in literature were compared with the SCFP biosorbent and the results are summarized in Table-4. From the present study it was found that the maximum biosorption capacity of SCFP biomass is found to have a relatively large biosorption capacity of $9.47 \mathrm{mg} \mathrm{g}^{-1}$ at $25 \pm$ $2{ }^{\circ} \mathrm{C}$ with $2 \mathrm{~g} \mathrm{~L}^{-1}$ biosorbent dosage. The biosorption capacity for $\mathrm{Co}$ (II) biosorption found in this study was comparable and was found to be higher than many other biosorbents, this indicates that it could be considered a promising material for the removal of $\mathrm{Co}$ (II) ions from aqueous solutions. From the results it was found that SCFP biomass appears to be economic as well as efficient biosorbent for the $\mathrm{Co}$ (II) removal from aqueous solutions.

\begin{tabular}{lcc} 
TABLE-4 \\
\multicolumn{3}{c}{ COMPARISON OF THE PRESENT SCFP BIOSORBENT } \\
MAXIMUM BIOSORPTION CAPACITIES (b, mg g ${ }^{-1}$ ) OF \\
Co(II) WITH VARIOUS BIOSORBENT \\
\hline \multicolumn{1}{c}{ Biosorbent } & Biosorption \\
& capacity (mg g-1) & Ref. \\
\hline Ficus religiosa (peepul) & 3.60 & 18 \\
Rhytidiadelphus squarrosus (moss) & 7.25 & 20 \\
Hypogymnia physodes (Foliose lichen) & 9.90 & 22 \\
Evernia prunastri (fruticose lichen) & 5.72 & 23 \\
R.arrhizus(fungi) & 2.90 & 24 \\
Saccharomyces cerevisiae & 5.80 & 24 \\
Schizandra chinesis Fruit peel & 9.47 & Present \\
& & study \\
\hline
\end{tabular}

Effect of ionic strength: Wastewaters from industries contain various types of suspended and dissolved compounds apart from the metal ions. These impurities could be acids, alkalis, salts or metal ions. Salt is an important factor to adverse the biosorption of metal ion. The effect of ionic strength $(\mathrm{NaCl})$ on cobalt biosorption was studied by changing $\mathrm{NaCl}$ concentration from 0.005 to $0.045 \mathrm{~mol} \mathrm{~L}^{-1}$ which is the level of salt in natural water at $25 \pm 2{ }^{\circ} \mathrm{C}$ and $10 \mathrm{mg} \mathrm{L}^{-1} \mathrm{Co}$ (II) initial concentration. The obtained results (Fig. 5) indicates that the increase concentration of ionic strength led to a slight decrease in the amount of adsorbed $\mathrm{Co}$ (II) this is due to the competitive interaction of salt ions and metal ions with surface active sites of biosorbent. However, the amount of adsorbed $\mathrm{Co}$ (II) was not significantly affected with ionic strength.

Desorption studies: The desorption studies of $\mathrm{Co}$ (II) from biomass were carried out with EDTA, $\mathrm{HCl}, \mathrm{HNO}_{3}$ and $\mathrm{Na}_{2} \mathrm{CO}_{3}$. As the concentration of desorbing solutions $\left(\mathrm{HCl}, \mathrm{HNO}_{3}\right.$ and EDTA) increases, more Co(II) ions were able to be desorbed.

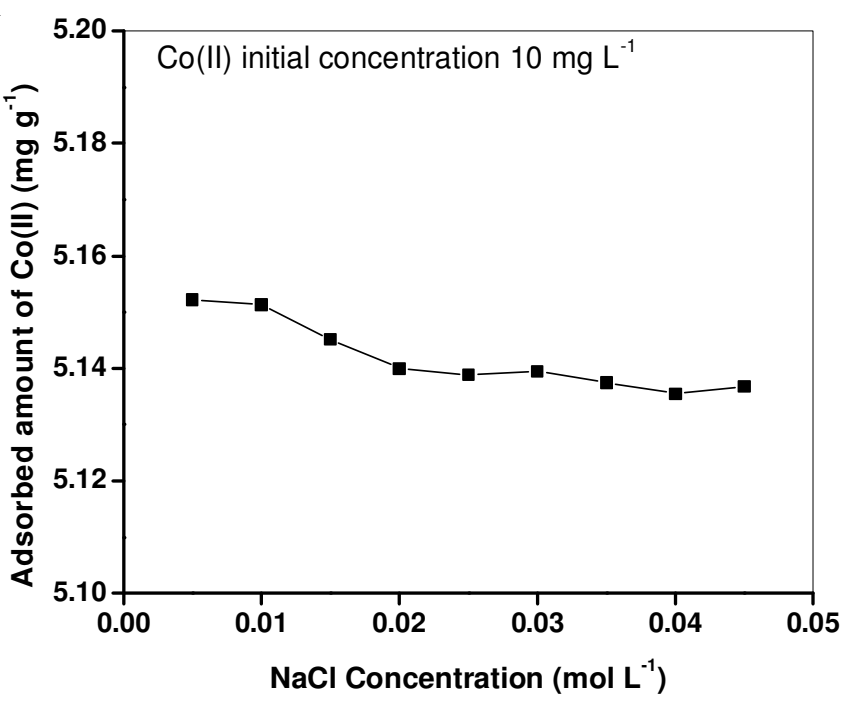

Fig. 5. Effect of ionic strength on biosorption of $\operatorname{Co}(\mathrm{II})$ on to $\operatorname{SCFP}\left(2 \mathrm{~g} \mathrm{~L}^{-1}\right)$ biosorbent at $10 \mathrm{mg} \mathrm{L}^{-1} \mathrm{Co}$ (II) initial concentration, $25 \pm 2{ }^{\circ} \mathrm{C}$ temperature and $200 \mathrm{rpm}$ shaking speed for $40 \mathrm{~min}$ equilibrium time

As shown in Table-5, more than $90 \%$ of Co(II) ions were able to be desorbed from biomass using $0.025 \mathrm{~mol} \mathrm{~L}^{-1} \mathrm{HCl}, \mathrm{HNO}_{3}$ and EDTA solutions. Especially, $98 \%$ of $\mathrm{Co}(\mathrm{II})$ recovery was achieved with $0.025 \mathrm{~mol} \mathrm{~L}^{-1}$ EDTA. This may be the stability of the aqueous $\mathrm{Co}$ (II)-EDTA complex is more than the $\mathrm{Co}$ (II)sorbent interactions. This result showed that the test biosorbent could be reused without significant losses in its initial adsorption capacity. It will help to elucidate the adsorption and desorption behaviour of $\mathrm{Co}$ (II) in aqueous solutions for recovery and recycling of adsorbent at particular treatment of effluents.

\begin{tabular}{ccc}
\multicolumn{3}{c}{ TABLE-5 } \\
DESORPTION STUDIES OF Co(II) FROM SCFP BIOSORBENT \\
\hline $\begin{array}{c}\text { Desorbing } \\
\text { solution }\end{array}$ & $\begin{array}{c}\text { Concentration of desorbing } \\
\text { solution (mol L-1) }\end{array}$ & $\begin{array}{c}\text { Desorption of metal } \\
\text { ion }(\%)\end{array}$ \\
\hline \multirow{3}{*}{ EDTA } & 0.001 & 56.45 \\
& 0.005 & 76.25 \\
& 0.010 & 87.24 \\
& 0.020 & 90.25 \\
& 0.025 & 98.26 \\
$\mathrm{HCl}$ & 0.001 & 22.56 \\
& 0.005 & 36.57 \\
& 0.010 & 85.28 \\
& 0.020 & 89.96 \\
& 0.025 & 92.15 \\
\hline $\mathrm{HNO}_{3}$ & 0.001 & 33.46 \\
& 0.005 & 49.98 \\
& 0.010 & 78.26 \\
& 0.020 & 90.26 \\
& 0.025 & 95.74 \\
\hline
\end{tabular}

Foreign ions effect on biosorption of $\mathrm{Co}(\mathrm{II})$ : For the determination of interference caused by the presence of other metal cations, $\mathrm{Ni}(\mathrm{II}), \mathrm{Li}(\mathrm{II}), \mathrm{Cu}(\mathrm{II})$ and $\mathrm{Pd}(\mathrm{II})$ were added to the Co(II) (10 $\left.\mathrm{mg} \mathrm{L}^{1}\right)$ solution. The obtained results were shown in Fig. 6. Presence of additional metal cations in the sorption medium in general was inhibitory to $\mathrm{Co}$ (II) biosorption by SCFP. This might be due to competition of divalent metal cations for complexation with the active binding sites of 


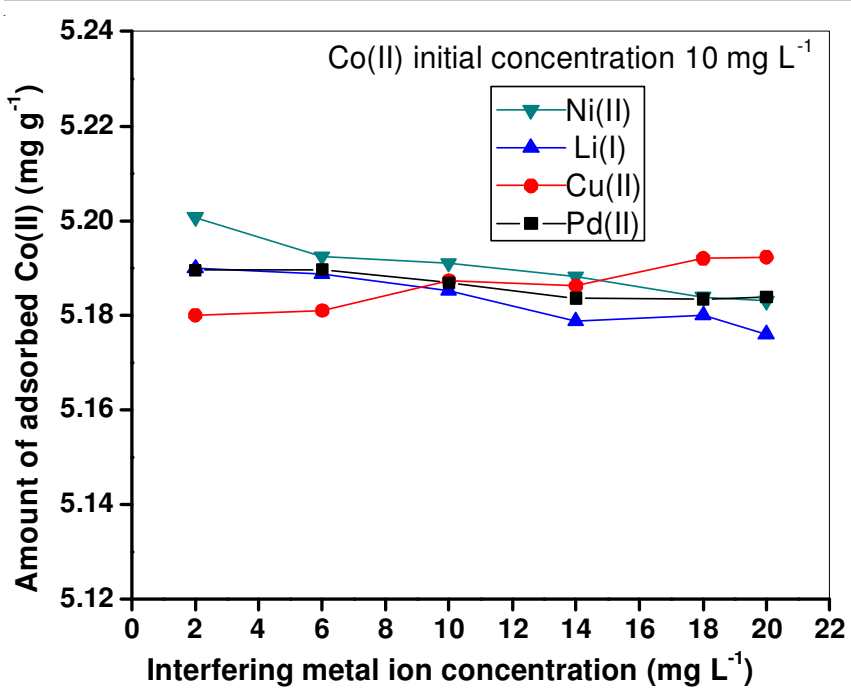

Fig. 6. Effect of associated metal ions on biosorption of $\mathrm{Co}$ (II) on to SCFP ( $\left.2 \mathrm{~g} \mathrm{~L}^{-1}\right)$ biosorbent at fixed $\mathrm{Co}(\mathrm{II})$ initial concentration $\left(10 \mathrm{mg} \mathrm{L}^{-1}\right)$, $25 \pm 2{ }^{\circ} \mathrm{C}$ temperature and $200 \mathrm{rpm}$ shaking speed for $40 \mathrm{~min}$ equilibrium time

biomass leading to decrease in $\mathrm{Co}(\mathrm{II})$ uptake. However, decrease of biosorption capacity of $\mathrm{Co}$ (II) was not significantly affect with associated metal ions which were studied here.

Biosorption mechanism: Biosorpiton is complex process therefore it is essential to understand mechanisms participating on the biosorption processes. Therefore, in our work we employed FTIR and SEM-EDX techniques to understand the biosorption mechanism.

The FT-IR spectrum of biomass (Fig. 7) shows a number of absorption peaks indicating the presence of various types of functional groups. A broad and strong absorption peak at $3433 \mathrm{~cm}^{-1}$ is observed this peak corresponds to aromatic and aliphatic $\mathrm{OH}$ groups. The peak at $3006.78 \mathrm{~cm}^{-1}$ indicating alkenes in aromatic ring and the strong peaks at 2926.22 and $2854.70 \mathrm{~cm}^{-1}$ are related to the $\mathrm{C}-\mathrm{H}$ vibration of alkyl and ethylene groups of side chains and aromatic methoxyl groups. A weak absorption peak at $2280.56 \mathrm{~cm}^{-1}$ corresponds to C-C triple bond at side chain of aromatic ring. The strong absorption peak at $1744.92 \mathrm{~cm}^{-1}$ assigned as carbonyl stretching vibrations. The absorption peak at $1638.28 \mathrm{~cm}^{-1}$ is indicating the aromatic ring alkenes while the peaks at 1460.51 and $1377.56 \mathrm{~cm}^{-1}$ are typical vibrations in alkynes skeleton on aromatic ring. The absorption peaks between 1319.54 and $1161.65 \mathrm{~cm}^{-1}$ indicating to $\mathrm{C}-\mathrm{O}$ stretching vibrations in side chains of aromatic ring units and the vibrations bands at 1059.76 and $804.11 \mathrm{~cm}^{-1}$ are indicating presence of substituted phenyl rings. The absorption peaks observed between 660.73 to $448.09 \mathrm{~cm}^{-1}$ related to $\mathrm{C}-\mathrm{X}\left(\mathrm{X}=\mathrm{Cl}^{-}, \mathrm{S}^{2-}\right)$ stretching vibrations. To identify the functional group that are involved in biosorption process FTIR spectra of $\mathrm{Co}$ (II) loaded biomass was compared with the FTIR spectra of biomass. The FT-IR spectrum of $\mathrm{Co}$ (II) loaded biomass (Fig. 7) indicating that the absorption peaks observed in SCFP biomass wavenumber were shifted, such as from 3433.28 to 3449.48 , from 2926.22 to 2928.81 , from 1744.92 to 1745.59 , from 660.73 to 722.41 and 448.06 to $424.15 \mathrm{~cm}^{-1}$. The shift in these peaks indicates the involvement of hydroxyl, methoxy and carbonyl functional groups in binding of $\mathrm{Co}(\mathrm{II})$.

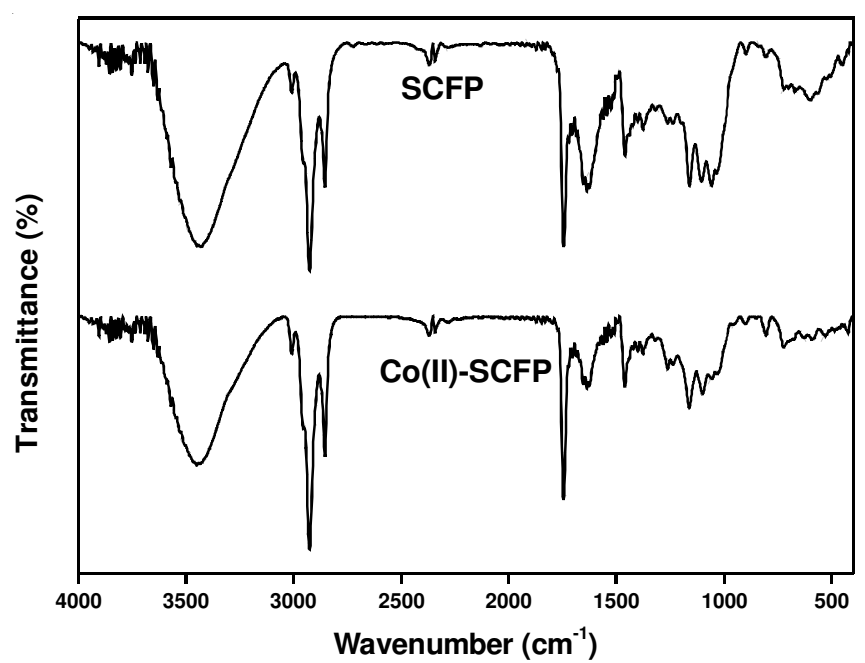

Fig. 7. FT-IR spectrum of SCFP biomass and Co(II)-SCFP biomass

Further SEM-EDX analysis was carried and the SEM morphology of biomass and metal loaded biomass were shown in Fig. 8. It was observed that the biomass has rough surface morphology this is favourable for biosorption of metal ions. The surface morphology of Co(II) loaded biomass (Fig. 8) exhibited different morphology than SCFP biomass, where shiny surface morphology was observed, indicating the surface of the SCFP biomass was covered by metal ions. The EDX analysis of SCFP biomass (Fig. 8) showed that the C was 65.93 weight $\%$ and oxygen was 29.46 weight $\%$ which are present in high percent and the calcium $(0.73$ weight $\%)$, sulfur $(1.35$ weight $\%$ ) and chlorine (2.54\%) are present in low percentage. The present of sulfur in SCFP is advantageous, because sulfur groups which are soft bases, have chemical affinity towards cobalt. Thus presence of sulfur in SCFP qualifies it as a potential adsorbent. From the overall results it was found that chemisorption plays an important role in the removal of $\mathrm{Co}$ (II) from aqueous solution by SCFP biosorbent.

Applications: The present bio-sorption method was successfully applied for the determination of Co(II) ions in synthetic water samples (Table-6). The synthetic water samples were prepared by adding various amounts of cobalt to the water samples. Calculated the relative standard deviation $(<1.052)$ and percentage of $\mathrm{Co}(\mathrm{II})$ recovery $(>99 \%)$ for the validation of measurements and method. It is clear from the results, the present green biosorption method was validated and aptly suited for the $\mathrm{Co}$ (II) recovery and determination without waste generation.

TABLE-6

RECOVERY AND DETERMINATION OF CO(II) FROM SYNTHETIC WATER SAMPLES USING SCFP BIOMASS AS BIOSORBENT

\begin{tabular}{ccccc}
\hline $\begin{array}{c}\text { Sample } \\
\text { No. }\end{array}$ & $\begin{array}{c}\text { Added Co(II) } \\
\left(\mathrm{mg} \mathrm{L}^{-1}\right)\end{array}$ & $\begin{array}{c}\text { Amount of found } \\
\mathrm{Co}(\mathrm{II})^{\mathrm{a}}\left(\mathrm{mg} \mathrm{L}^{-1}\right)\end{array}$ & $\begin{array}{c}\text { RSD } \\
(\%)\end{array}$ & $\begin{array}{r}\text { Recovery of } \\
\mathrm{Co}(\mathrm{II})(\%)\end{array}$ \\
\hline 1 & 5.0 & 4.96 & 1.023 & 99.20 \\
2 & 10.0 & 10.12 & 0.945 & 101.20 \\
3 & 12.0 & 11.98 & 0.532 & 99.80 \\
4 & 18.0 & 19.01 & 0.982 & 105.60 \\
5 & 20.0 & 19.87 & 1.052 & 99.35 \\
6 & 22.0 & 21.98 & 0.794 & 99.90 \\
\hline
\end{tabular}

${ }^{\mathrm{a}}$ Average of five determinations. 

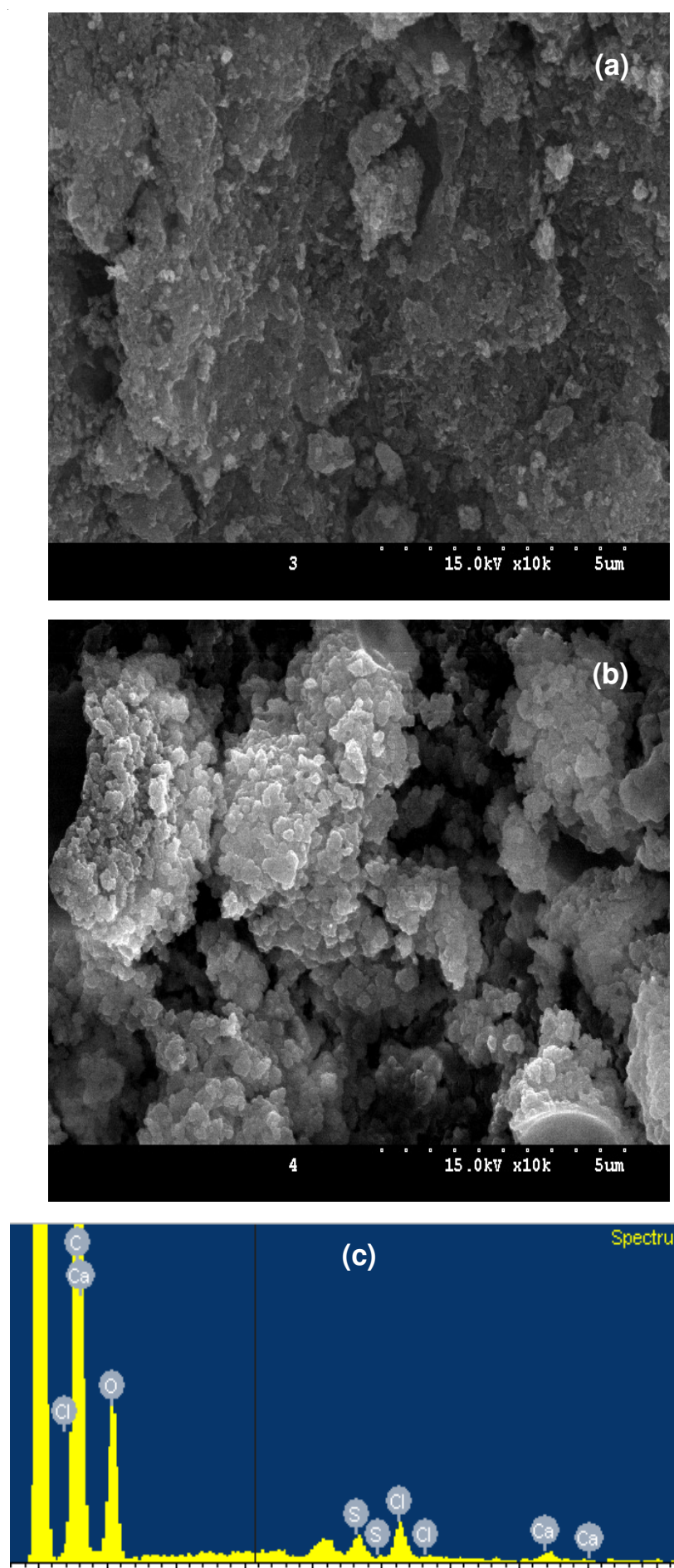

(c)

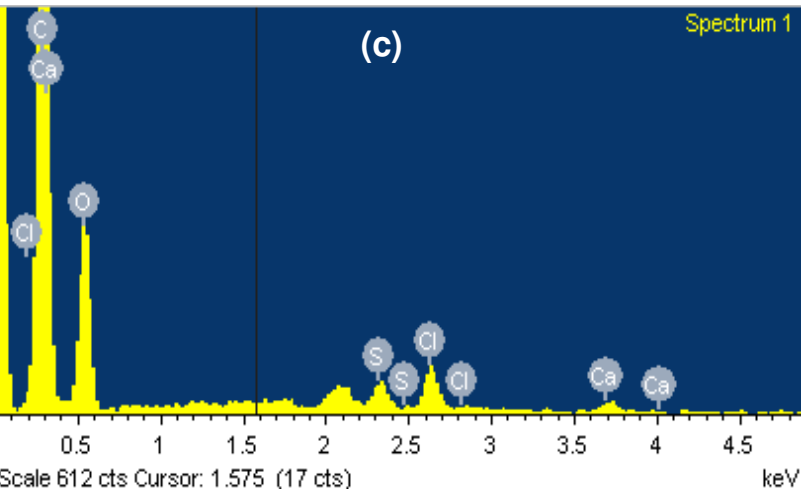

Full Scale 612 cts Cursor: 1.575 (17 cts)

$\mathrm{keV}$

Fig. 8. Surface morphology (SEM images) of (a) Before biosorption of Co(II) on to SCFP, (b) after biosorption of Co(II) on to SCFP biosorbent at same magnifications and (c) SEM-EDX spectrum of SCFP biosorbent

\section{Conclusion}

Schizandra chinesis fruits peel (SCFP) was an eco friendly potential biosorbent for heavy metals removal. This work examined the efficiency of this sorbent in the removal of $\mathrm{Co}$ (II) ions from the aqueous solutions. Biosorption affected by various parameters, such as biomass concentration, $\mathrm{pH}$ and temperature was studied. The kinetic studies revealed that the biosorption process followed the pseudo-second order kinetic model. Adsorption isotherm models such as Freundlich, Langmuir and Temkin models to the biosorption data of Co(II) for evaluation of adsorption efficiency of the biosorbent. The maximum biosorption capacity of $\mathrm{Co}$ (II) was $9.47 \mathrm{mg} / \mathrm{g}$ at $25 \pm 2{ }^{\circ} \mathrm{C}$ with $2 \mathrm{~g} \mathrm{~L}^{-1}$ adsorbent dosage and an optimum $\mathrm{pH}$ 6.5 , which indicating that the present biomass was considered to be promising and potential biosorbent for the removal of $\mathrm{Co}(\mathrm{II})$. The biosorption capacity of present SCFP was near or more than the reported results of various biosorbents sorption capacity. This may be successful application for the regular adsorption/biosorption of metal ions in the large scale from metallurgical industries.

\section{ACKNOWLEDGEMENTS}

This research work was supported by the Research Grant-2013 from Kwangwoon University, Seoul. The authors are also grateful to the Korea Ministry of Environment for partially supporting of this research work by funding The GAIA Project (Sanction no: G111-17003-0038-2).

\section{REFERENCES}

1. N. Unlu and M. Ersoz, J. Hazard. Mater., 136, 272 (2006).

2. Q. Yu, T. Matheickal, P. Yin and P. Kaewsarn, Water Res., 33, 1534 (1999).

3. http://www.lenntech.com/periodic/elements/co.htm.

4. R. Lauwerys and D. Lison, Sci. Total Environ., 150, 1 (1994).

5. S. Rengaraj and S.H. Moon, Water Res., 36, 1783 (2002).

6. F.V. Goethem, D. Lison and M. Kirsch-Volders, Mutation Res./Genet. Toxicol. Environ. Mutagen., 392, 31 (1997).

7. C. White and G.M. Gadd, FEMS Microbiol. Lett., 38, 277 (1986).

8. A. Bhatnagar, A.K. Minocha and M. Sillanppa, Biochem. Eng. J., 48, 181 (2010).

9. D.M. Manohar, B.F. Noeline and T.S. Anirudhan, Appl. Clay Sci., 31, 194 (2006).

10. M. Hamdi Karaoglu, U. Mehmet and K. Ibrahim, Bioresources, 6, 1954 (2011).

11. A. Ahmadpour, M. Tahmasbi, T.R. Bastami and J.A. Besharati, J. Hazard. Mater., 166, 925 (2009).

12. N. Ahalya, T.V. Ramachandra and R.D. Kanamadi, Res. J. Chem. Environ., 7, 71 (2003).

13. M. Ebrahimi, R. Panahi and R. Dabbagh, Appl. Biochem. Biotechnol., 158, 736 (2009).

14. G. Rich and K. Cherry, Hazardous Waste Treatment Technologies, Pudvan Publishers, New York, USA (1987).

15. Y.C. Lee and S.P. Chang, Bioresour. Technol., 102, 5297 (2011).

16. L. Ruta, C. Paraschivescu, M. Matache, S. Avramescu and I.C. Farcasanu, Appl. Microbiol. Biotechnol., 85, 763 (2010).

17. M. Hornik, M. Pipiška, M. Kociová, J. Augustin and J. Lesný, Cereal Res. Commun., 36 (Suppl. 5), 419 (2008).

18. B. Krishna and P. Venkateswarlu, Indian J. Chem. Technol., 18, 381 (2011).

19. J. Marešová, M. Hornik, M. Pipiška and J. Augustin, Nova Biotechnol., 10, 45 (2010).

20. J. Maresova, M. Pipiska, M. Rozloznik, M. Hornik, L. Remenárová and J. Augustin, Desalination, 266, 134 (2011).

21. H. Mohapatra and R. Gupta, Bioresour. Technol., 96, 1387 (2005).

22. M. Pipiška, M. Hornik, L. Vrtoch, J. Augustin and J. Lesný, Biologia (Bratisl.), 62, 276 (2007).

23. M. Pipiška, M. Hornik, L. Vrtoch, J. Augustin and J. Lesný, Chem. Ecol., 24, 181 (2008).

24. S.S. Ahluwalia and D. Goyal, Bioresour. Technol., 98, 2243 (2007).

25. M.D. Bordalo, J. Pratas and M.A. Pardal, Water Air Soil Pollut., 224, 1518 (2013).

26. S.K. Chatterjee, I. Bhattacharjee and G. Chandra, J. Hazard. Mater., 175, 117 (2010).

27. P.Y. Deng, W. Liu, B.Q. Zeng, Y.K. Qiu and L.S. Li, Int. J. Environ. Sci. Technol., 10, 559 (2013). 
28. F. Ekmekyapar, A. Aslan, Y.K. Bayhan and A. Cakici, J. Hazard. Mater, 137, 293 (2006).

29. V.K. Gupta, D. Pathania, S. Agarwal and S. Sharma, Environ. Sci. Pollut. Res., 20, 2632 (2013).

30. Y. Liu, Q. Cao, F. Luo and J. Chen, J. Hazard. Mater, 163, 931 (2009).

31. S.K. Garg, M. Tripathi, S.K. Singh and A. Singh, Environ. Sci. Pollut. Res., 20, 2288 (2013).

32. M.S. Al-Masri, Y. Amin, B. Al-Akel and T. Al-Naama, Appl. Biochem. Biotechnol., 160, 976 (2010).

33. H. Elifantz and E. Tel-Or, Water Air Soil Pollut., 141, 207 (2002).

34. U.M.K. Nagpal, A.V. Bankar, N.J. Pawar, B.P. Kapadnis and S.S. Zinjarde, Water Air Soil Pollut., 215, 177 (2011).

35. S. Nigam, K. Gopal and S.V. Padma, Environ. Sci. Pollut. Res, (2012). (In press); 10.1007/s11356-012-1342-X.

36. H.J. Lee and C.Y. Kim, Food Chem., 120, 1224 (2010).

37. A. Panossian and G. Wikman, J. Ethnopharmacol., 118, 183 (2008).

38. B.L. Wang, J.P. Hu, W. Tan, L. Sheng, H. Chen and Y. Li, J. Chromatogr. B Analyt. Technol. Biomed. Life Sci., 865, 114 (2008).

39. C. Ozer, M. Imamoglu, Y. Turhan and F. Boysan, Toxicol. Environ. Chem., 94, 1283 (2012).
40. H. Serencam, D. Ozdes, C. Duran and M. Tufekci, Environ. Monit. Assess., 185, 6003 (2013).

41. C.P. Huang, M.W. Tsang and Y.S. Hseigh, AIChE Symp. Ser., 243, 85 (1985).

42. K. Anoop Krishnan and T.S. Anirudhan, J. Hazard. Mater., 92, 161 (2002).

43. I.G. Shibi and T.S. Anirudhan, Ind. Eng. Chem. Res., 41, 5341 (2002).

44. S. Lagergren, Handl., 241, 39 (1898).

45. Y.S. Ho, J.C.Y. Ng and G. Mckay, Sep. Purf. Methods, 29, 189 (2000).

46. G. Dursun, H. Cicek and A.Y. Dursun, J. Hazard. Mater., 125, 175 (2005).

47. J. Eastoe and J.S. Dalton, Adv. J. Colloid Interf. Sci., 85, 103 (2000).

48. I. Langmuir, J. Am. Chem. Soc., 38, 2221 (1916).

49. B.H. Hameed, D.K. Mahmoud and A.L. Ahmad, J. Hazard. Mater. 158, 65 (2008).

50. K.R. Hall, L.C. Eagleton, A. Acrivos and T. Vermeulen, I\&EC Fundam., 5, 212 (1966)

51. H.M.F. Freundlich, J. Phys. Chem., 57(A),385 (1906),

52. M.J. Temkin and V. Pyzhev, Acta Physicochem. URSS, 12, 217 (1940). 